\title{
The imaging spectrum of neuro-Behçet disease
}

Figure Imaging features of neuro-Behçet disease
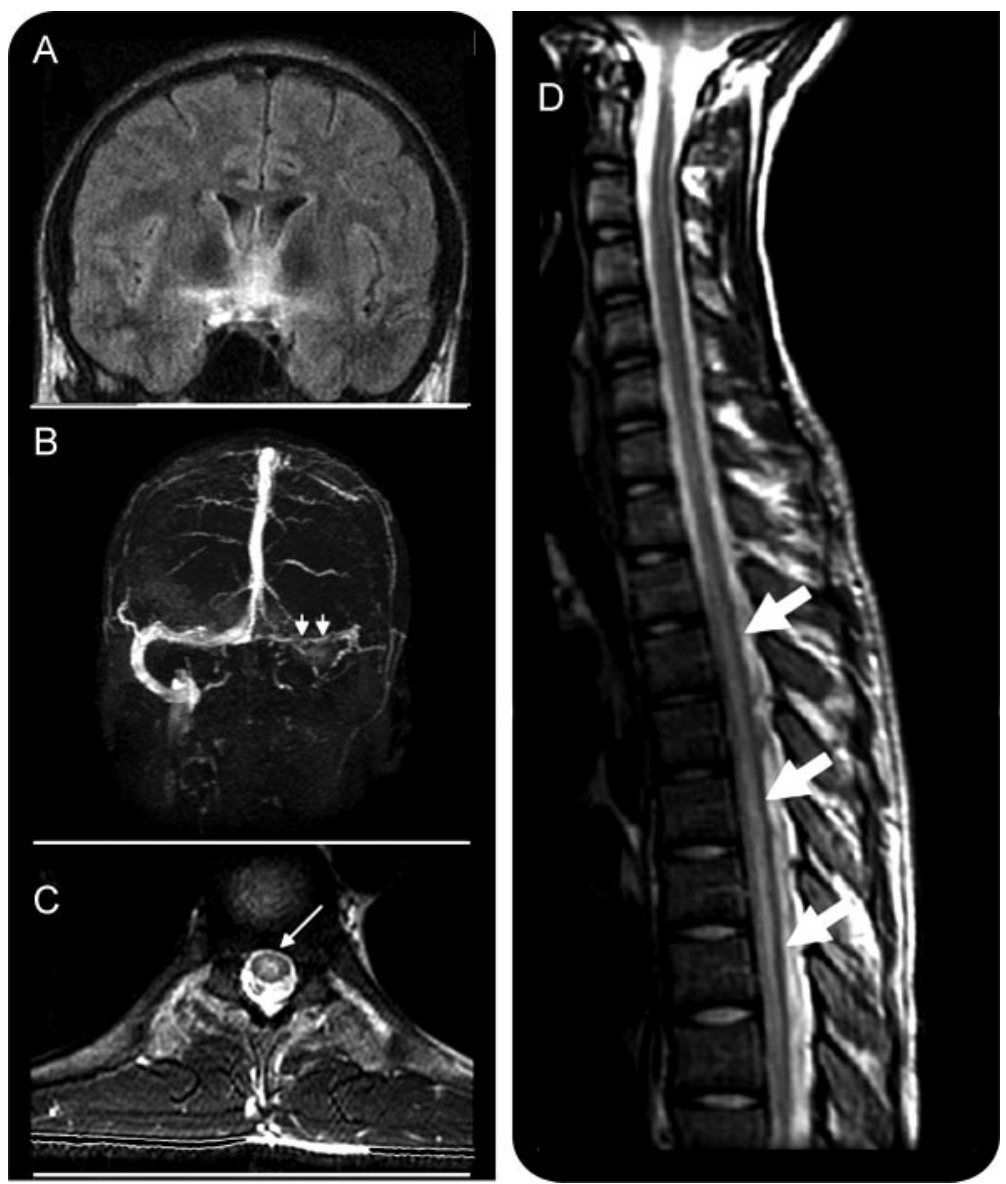

(A) Coronal fluid-attenuated inversion recovery sequence shows periventricular, chiasmatic, and hypothalamic edema. (B) Magnetic resonance venography reveals left transverse sinus thrombosis. (C) Axial T2-weighted sequence shows high signal primarily within the spinal cord gray matter. (D) Sagittal T2-weighted sequence demonstrates high signal intensity longitudinally throughout the cervical and thoracic spinal cord.
An 18-year-old man with recurrent oral and genital ulcers presented with uveitis, encephalopathy, headache, spastic paraparesis, and urinary retention. MRI demonstrated periventricular and hypothalamic lesions, sinus thrombosis, and longitudinally extensive spinal cord lesions (figure). Treatment with highdose steroid medication resulted in dramatic neurologic and radiographic improvement.

Behçet disease is a multisystemic inflammatory disease characterized by recurrent oral aphthae, uveitis, and genital ulcers. Two patterns of CNS involvement have been described, including direct parenchymal involvement and cerebrovascular involvement. ${ }^{1}$ Simultaneous symptomatic parenchymal, vascular, and spinal cord lesions characteristic of neuro-Behçet disease in a single patient are highly unusual.

\section{S. Taylor, $M S c, M D$, O. Islam, MD, FRCPC,} M. Joneja, $M D, M E d, F R C P C$,

M. Melanson, MD, FRCPC, A.Y. Jin, PhD, MD, FRCPC, Kingston, Ontario, Canada Disclosure: The authors report no disclosures.

Address correspondence and reprint requests to Dr. Albert Y. Jin, Department of Medicine (Neurology), Queen's University clo Connell 7, Division of Neurology, Kingston General Hospital, Kingston, Ontario,CanadaK7L2V7; ayj@queensu.ca

1. Al-Araji A, Kidd DP. Neuro-Behcet's disease: epidemiology, clinical characteristics, and management. Lancet Neurol 2009;8:192-204. 


\section{Neurology}

\section{The imaging spectrum of neuro-Behcet disease}

S. Taylor, O. Islam, M. Joneja, et al.

Neurology 2009;73;903

DOI 10.1212/WNL.0b013e3181b784ac

This information is current as of September 14, 2009

\section{Updated Information \&} Services

References

Subspecialty Collections

Permissions \& Licensing

Reprints including high resolution figures, can be found at: http://n.neurology.org/content/73/11/903.full

This article cites 1 articles, 0 of which you can access for free at: http://n.neurology.org/content/73/11/903.full\#ref-list-1

This article, along with others on similar topics, appears in the following collection(s):

\section{All Medical/Systemic disease}

http://n.neurology.org/cgi/collection/all_medical_systemic_disease All Spinal Cord

http://n.neurology.org/cgi/collection/all_spinal_cord

Autoimmune diseases

http://n.neurology.org/cgi/collection/autoimmune_diseases

Cerebral venous thrombosis

http://n.neurology.org/cgi/collection/cerebral_venous_thrombosis

MRI

http://n.neurology.org/cgi/collection/mri

Information about reproducing this article in parts (figures,tables) or in its entirety can be found online at:

http://www.neurology.org/about/about_the_journal\#permissions

Information about ordering reprints can be found online: http://n.neurology.org/subscribers/advertise

Neurology ${ }^{\circledR}$ is the official journal of the American Academy of Neurology. Published continuously since 1951, it is now a weekly with 48 issues per year. Copyright . All rights reserved. Print ISSN: 0028-3878. Online ISSN: 1526-632X.

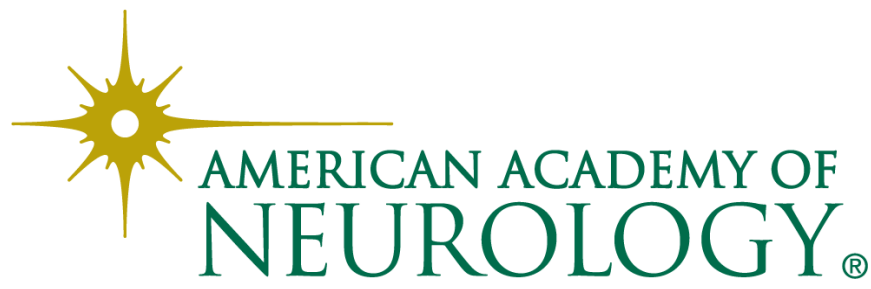

